\title{
Формирование смысложизненных стратегий личности
}

Смысловые стратегии - динамическая составляющая смысловой сферы. Они предстают смысловыми новообразованиями личности, изменяющими всю смысловую структуру. Механизм формирования смысложизненных стратегий определяется рядом факторов:особенностями мотивационно-интенциальной сферы, хронологическим возрастом, жизненным контекстом, социокультурными иэкономическими условиями и представляет собой сложный многомерный процесс.

Ключевые слова: смысловые образования, смысложизненная концепчия, смысложизненные стратегии, уровни смыслового развития.

Стремление описать динамику формирования смысловой сферы через достаточно устойчивые стратегии породило стремление к упорядоченности, естественному желанию расположить смыслы в системном порядке в зависимости от специфики смысловых образований личности. Наиболее очевидным предстает диадная природа смысла, его континуумная динамика от минимального к максимальному насыщению: от становящегося смысла - к ставшему, от неопределенного смысла - к определенному (в рамках ценностного отношения), от постигаемого смысла - к постигнутому. При таком подходе просматривается закономерная последовательность как интегральная динамическая характеристика индивидуального сознания обнаруживается в последовательности «от смыслового следа - к категориальному обозначению смысла в его явленном виде» и, собственно, соответствует той логике процесса смыслообразования, которая выявляется нами в рамках интегративного подхода как смысловая направленность, т.е. смысловая стратегия.

Факты динамики смыслообразования, демонстрируют «смысловую нарастаемость», «смысловое восхождение», «смысловое обогащение» сознания. Это один вид смысловой стратегии, однако, имеет место и обратный вариант, выражающий, например, угасание смысла, его поглощаемость другим, вытеснение, регрессию. При этом, в зависимости от конкретного содержания смыслов, развитие смысловой сферы личности может оцениваться как со знаком «плюс», так и со знаком «минус», а также неопределенным образом.

Естественный, закономерный характер формирования смысловых стратегий здесь проявляется в относительно простых смысловых условиях, когда условно смысловые проявления мы сводим к моносмысловому (одноактному) варианту. Если же учесть, что деятельность и поведение человека регулируются обычно множеством смыслов (смысловые проявления всегда полисмысловые), их сложным взаимодействием, то сложный и неопределенный характер имеет и процесс 
смыслообразования, представленный в полной мере. Достаточно обратиться к факту какого-либо неожиданно, непредсказуемо открывшегося человеку смысла (смена жизненных отношений, инсайт), «переворачивающего» его сознание, чтобы понять феноменологическую неопределенность смысложизненных стратегий.

Решая проблему специфики формирования смысловых стратегий, в иной формулировке - развития смысловой сферы человека, логично обратиться к ставшим уже классическими в психологии «зонам развития» (Л.С. Выготский). Такое обращение тем более логично, что психические новообразования в нашем исследовании выступают как смысловые новообразования. Экспериментальные исследования смысловой сферы личности (В.К. Вилюнас, Д.А. Леонтьев, И.В. Абакумова) свидетельствуют, что известная психологическая последовательность «вхождение в зону развития - зона актуального развития - зона ближнего развития - зона саморазвития» является детерминирующей и в тенденциях смыслообразования. Закономерность развития смысловой сферы личности может быть выражена и отдельным блоком войти в модель смыслообразования человека как последовательность, содержащая вхождение в зону смыслообразования, зону актуального развития смысловой сферы, зону ее ближайшего развития, зону саморазвития. «Зоны развития» в нашей модели - это прежде всего зоны развития стержневой основы личности, ее смысловой структуры. В этой же последовательности «зон» формируются смысловые структуры и других уровней. Конкретизации различных зон посвящены последующие разделы. Здесь же заметим, что в теории поэтапного формирования умственных действий, в которой акцент делается на ориентировочной основе действий как преддверии исполнительской части деятельности, сама ориентировочная основа действий может быть истолкована как феномен вхождения в зону смыслового развития. Главные движущие силы процесса развития, интерпретируемые с позиций смыслового неравновесия, смысловых несоответствий и противоречий, находят свое методологическое объяснение в зоне ближайшего развития смысловой сферы личности, которая детерминирует смыслообразование в определенных границах, доступных познающему субъекту и является основой динамической составляющей смысловой сферы - смыслообразовательной стратегии..

Каков же механизм формирования смысложизненных стратегий?

По мнению ряда авторов, исследовавших смысл в психологии (К. Роджерс, В. Франкл, Д.А. Леонтьев, Н.Е. Щуркова), исходным условием возникновения смыслов, источником смыслообразования и формирования смысложизненных стратегий, является жизненный мир человека. Указанный мир заметно отличается от «общего» мира, с явлениями, фактами, событиями и другими фрагментами которого человек большей частью не сталкивается. Эта часть мира, отчужденная от конкретной личности, представлена, в частности, реальной действительностью и отражающими ее объективными значениями, запечатленными в текстах культуры. Культура функционирует и в нетекстовой форме, как реальное бытие, в виде действительных отношений и норм поведения людей. При этом реальное бытие 
культуры и реальное бытие человека, и уж тем более бытие «вообще», как правило, не совпадают, мир действительного бытия оказывается шире бытия культуры. Особой частью культуры является ее художественный сегмент, образуемый не объективными значениями, а «откристаллизованными», «опредмеченными» субъективными смыслами тех, кто эту часть культуры создавал. Поскольку, однако, текст не есть смысл, это лишь место, указывающее на смысл, то текстовая художественная культура, пока с нею не вошел в соприкосновение субъект, может быть квалифицирована как объективная структура значений.

В отличие от мира «в целом», жизненный мир человека - это мир его отношений с явно ограниченной частью действительности. Одни ее фрагменты имеют для него большее значение, и замыкание на них его субъектного опыта, его жизненных отношений более интенсивно и динамично, другие - меньшую жизненную значимость, и отношение к ним со стороны субъекта может быть менее выразительным, третьи могут быть представлены лишь потенциально. Эти отношения определяются в науке как жизненные смыслы. Их возникновение, становление и развитие, осуществляемые, естественно, в субъективной сфере индивидуума, обусловлены тем не менее жизненной детерминантой данной личности и выражают жизненную необходимость, имеют конкретно объективный характер.

Жизненные смыслы, возникая из реальной потребности человеческого бытия и образуя жизненный мир субъекта, могут быть, на наш взгляд, отнесены к разряду актуальных смыслов и включены в область актуальных смысловых отношений. В сопоставлении с этим, жизненные смыслы, возникающие из объективной жизненной необходимости относительно не входящих в жизненное пространство конкретно данного человека ценностей, нами относятся к категории актуальных смыслов. Любой факт действительности, попав в жизненную орбиту человека, может инициировать возникновение смыслового к нему отношения и стать рефлексивно поглощенным «Я-концепцией», наполняя ее новым смысловым содержанием. А.Н. Леонтьев писал: «Смысл определяется жизнью», и действительно, возможности формирования смысложизненных стратегий продуцируются через вхождение «большого мира» в жизненный мир человека. 